\title{
Cultural Infiltration of Foreign Literary Works in Senior High School Chinese Textbooks
}

\author{
Li Gao* \\ School of Education, Qufu Normal University, Qufu 273165, Shandong Province, China \\ *Corresponding author: Li Gao, $626986168 @ q q . c o m$
}

\begin{abstract}
Foreign literary works are an important part of Chinese textbooks in high schools. However, the exam-oriented education results in a marginalized and unsatisfactory teaching of foreign literary works. Based on the high school Chinese textbook by PEP (People's Education Press), teaching practices, and requirements of the new curriculum standards, this article analyzes the foreign literary works in the textbook, explores its value and the infiltration of cultural spirit in teaching, discusses the problems in teaching, as well as provides suggestions to them in hope to gain attention in the teaching of foreign literary works, broaden students' horizons, and cultivate their humanistic spirit.
\end{abstract}

Keywords: PEP (People's Education Press) edition; High school Chinese textbooks; Foreign literary works; Textbook analysis; Cultural infiltration

Publication date: August 2021; Online publication: August 30, 2021

\section{Introduction}

Foreign literary works are valuable spiritual wealth of the world's cultural heritage. They are not only carriers of different cultures, which would help students appreciate cultural diversity, but also an important window for students to broaden their horizons and see the world. They have important educational value. Therefore, the education of foreign literature should be emphasized to improve students' knowledge, ability, and personality along with cultivating their humanistic spirit.

\section{Reasons and value of foreign literary works in senior high school Chinese textbooks}

The Chinese discipline has always been an important stage to reflect the mainstream culture of the society and play the role of "writing is for conveying truth." Therefore, excellent literary works from various countries have been incorporated into high school Chinese textbooks, mainly Chinese literature but supplemented with foreign literature. Learning and studying the treasures in the history of foreign development can help students to understand the world and national culture while helping them to learn more about foreign cultures, expand their horizons, and improve their knowledge structure. Moreover, foreign literature enriches their spiritual world with its unique artistic charm. It can be said that foreign literary works in Chinese textbooks carry the dual tasks of cultural communication and education.

\subsection{Cultivate students' multicultural perspective}

The former Secretary-General of the United Nations, Ban Ki-moon, delivered a speech "In the Name of the Future" with the theme of "The Common Cultural Mission of Mankind." He believes that multiculturalism is an opportunity rather than a threat. After that, he also proposed the view of "cultivating students' multicultural perspective." There is no doubt that the concept of multiculturalism is in line with social 
development. Not only is the Chinese culture broad and profound, but also requires students to study in depth. Foreign culture also has its essence, in which it has value for the learning of students.

Through the analysis of the textbook, it can be appreciated that the textbook has selected literary works from different countries and extensively absorbed the essence of foreign cultures so that students can be exposed to the cultural situation of different countries, understand the history and culture of foreign countries, and cultivate students' multicultural perspective. For example, Chekhov's "The Man in a Case" depicts a Russian society reflecting a case against the background of Russia under the rule of tsarist Russia in the late $19^{\text {th }}$ century. Other than that, "Hamlet" portrays the life situation and power struggle of Nordic nobles while "The Old Man and the Sea" by Hemingway gives a sense of the Cuban beaches and allows people to experience the life of a tough fisherman. Foreign literary works with strong multicultural elements in high school Chinese textbooks can build a bridge for cultural exchange, cultivate students' multicultural perspective, and share different cultures.

\subsection{Cultivate humanistic spirit and improve educational function}

The new curriculum standards require the cultivation of students' humanistic spirit, the enhancement of their spiritual realm, edification of their moral sentiments, and the shaping of excellent personalities through the Chinese teaching in senior high school. The humanistic spirit has always been regarded as the essence of foreign literary works. Learning and understanding the humanistic spirit in foreign literary works allow people to experience the warmness of human feelings and the world's fickleness. They do not only provide knowledge but also spiritual food. Therefore, in that sense, literary works serve to cultivate students' humanistic spirit and sublimate their ideological realm.

The foreign literary works in high school Chinese textbooks by PEP embody the humanistic spirit of working in unity and close cooperation, courage, strength, optimism, patriotism consciousness, and so on. For example, "The Old Man and the Sea" reflects bravery in facing failures and taking risks in addition to giving a sense of positive and enterprising humanistic spirit; "Man is a Reed that Thinks," "Credo," and "Love of Life" emphatically reflect the correct values of life; "The Future of the Universe" is a speech by Stephen Hawking on cosmic science, which portrays the charm of science and piques students' interests in the scientific world in order to explore the unknown world. Promoting humanistic spirit can enrich students' spiritual world and enrich their minds.

\section{Teaching requirements of the new curriculum standards for Chinese and foreign literary works in senior high school}

The core quality of the Chinese discipline is highlighted in the new Chinese curriculum standards for senior high school, which mainly include four aspects: language construction and application; thinking development and promotion; aesthetic appreciation and creation; cultural inheritance and understanding. The new curriculum standards integrate the core quality into four unified aspects, which are not independent but complementary. As important carriers of culture, language construction and application have become the basis and core of the whole scientific literacy. In addition, the new curriculum standards also emphasize the importance of improving students' thinking ability, aesthetic appreciation, and cultural inheritance. At the same time, the new curriculum standards highlight the importance of culture and education, define the main tasks in Chinese teaching, and provide a supporting basis for the study of foreign literature ${ }^{[1]}$.

The new curriculum standards have relatively clear standards for the appreciation and learning of foreign literary works in Chinese high schools. In the process of learning foreign literary works, students' appreciation and aesthetic experience should be cultivated along with their emotions and sentiments. As for the study of foreign literary works in textbooks, it is advocated that teachers should guide students to 
learn more about foreign cultures, realize the differences between Chinese and foreign cultures, and respect the diversity of world cultures.

The new Chinese curriculum standards for senior high school require students to explore the differences between national literature and foreign literary works as well as to establish the concept of respecting cultural diversity in the teaching of foreign literary works. The cultural characteristics of different regions in the world vary greatly. Each nation has its own unique cultural heritage, and different nations have different ways of thinking. Therefore, in the teaching process, it is necessary to be openminded in order to explore and understand foreign literary works, instead of being restricted by the fixed Chinese mode of thinking to prevent misunderstandings. Therefore, it is necessary to establish a teaching concept that respects cultural diversity.

\section{Embodiment of the cultural spirit in high school Chinese and foreign literary works}

\subsection{Connotations of culture}

American scholar, Sam, believes that the sum of the characteristics of a group which differ from other groups is in the cultural spirit. Culture is formed through a long historical process and accumulation of human beings, and it is the result of long-term accumulation and precipitation in the human social practice. With continuous improvement of human productivity, more and more cultures are being created by human beings. Cultural spirit, as a value concept and pursuit, is continuously condensed and inherited in the process of social practice.

In western culturology, cultural spirit is also known as "national spirit" or "national soul." Cultural spirit is the inheritance of excellent human cultural gene. It can cultivate people to form a correct world outlook, outlook on life, and values. It is the soul of the nation.

\subsection{Infiltration of cultural spirit in the Chinese teaching at senior high schools}

In the west, cultural spirit confers humanism as the core, advocates freedom and rationality, as well as emphasizes human value and dignity. It is a valuable spiritual wealth around the world. Therefore, the selection of foreign literary works in Chinese textbooks also fully reflects the western cultural spirit.

\subsubsection{Individual heroism}

According to the interpretation of $\mathrm{Ci}$ Hai, heroism refers to the courage, tenacity, and self-sacrifice in the initiative to complete tasks of great significance. Western heroism mainly emphasizes individual heroism; it emphasizes that man is a free and independent individual as well as advocates the realization of selfvalue. Heroism in Chinese cultural spirit mainly refers to collective heroism, which focuses on unity and cooperation, sacrifices the ego, obeys the overall situation, and emphasizes that individual value is realized through collective value. The western individual heroism is a spirit of saving the world and expressing the struggle against the fate whereas the Chinese collective heroism involves the spirit of sacrifice and a compromise to fate.

Hemingway's allegorical novel, "The Old Man and the Sea," that has been selected from the textbook reflects the western individual heroism, in which the protagonist, Santiago, is a hero who struggles with nature alone. Through his experience of fishing at sea, the old man failed; however, after he landed on shore, he said, "A man can only be defeated, but cannot be conquered," which made people feel he had a fearless heroic spirit, and it successfully shaped a "tough man" image that would never give in. Learning "The Old Man and the Sea" allows students to experience the fearless spirit of the old man, learn his tenacious will, encourage students to face failures and meet challenges bravely, as well as cultivate their spirit of never giving up and fighting on tenaciously. 


\subsubsection{Consciousness of cherishing life}

"The most precious thing is life. Life only comes once for everyone. How should we spend our life?" "Love of Life," one of Montaigne's representative works in the compulsory four textbooks, discusses the meaning of life and emphasizes the consciousness of cherishing life embodied in humanism.

It is introduced in the context of "living" and separated into killing time and enjoying good time so as to connect the two different views on life along with cherishing life. Life is very precious. Its value is reflected very differently from a stage rehearsal which can be repeated; no matter what kind of people, poor or rich, healthy or ill, life comes only once and it cannot be repeated. People cannot choose their own destiny; the only thing they can cherish is the life in front of them. A confused person's life is boring and restless, but he places all his hopes in the afterlife. Borrowing a sentence from Seneca, an ancient Roman philosopher, it shows the author's grasp of life. For Montaigne, this was a slap in the face for the ethereal souls whose happiness depended on God rather than themselves. Cherishing life is to grasp the present and not the afterlife. The hope lies in life itself rather than other ethereal existence. In this way, students would be able to have a clearer understanding of the significance of cherishing and loving life.

Both, eastern and western people, have affirmed the value of life, but there are still great differences. The westerners' worship of life created their culture's affirmation of the value of life and the worship of spiritual culture. Therefore, westerners regard the noumenon of life above everything else and try their best to survive in danger in the battlefield so that their lives will not be threatened. However, ancient Chinese people had advocated killing one's body to achieve humanity and sacrificing one's life for justice. They would rather die than ignobly live. They attached importance to the embodiment of spiritual values but neglect the value of life itself. Therefore, in Chinese teaching, it is necessary to cultivate students' sound outlook on life, explore the meaning of life, and cherish it.

\subsubsection{Strong sense of tragedy}

Nietzsche believes that tragedy is the "most noble art" of all arts ${ }^{[2]}$, in which it makes people feel a shocking sense of sublimity, because the outcome of western traditional tragedies often paints a picture where the heroes would use their lives to prove the thoroughness and significance of struggle, as is the case with Hamlet.

As a representative of the bourgeoisie, Hamlet fought against the powerful feudal forces as a humanist, and his tragedy was not only the tragedy of the era, but also of humanism. Several changes in the family and social problems made him pursue freedom and liberation while questioning the human nature. There was a conflict between his plump ideal and bony reality, bearing a great spiritual blow. In this sharp contradiction, Hamlet puts forward the ultimate thinking of life "survival or destruction." This is not only a question of life and death, but also the value evaluation of everything. His self-criticism, negation, and self-questioning of the soul led him to a tragic end, which made him a classic tragic figure and also the embodiment of the western tragic spirit.

Compared with the western tragic sublimity, the Chinese tragedy is different. Several people have summed up the difference between the Chinese and Western tragedies in a way that in ancient Greek tragedy, as defined by Aristotle, the plot must "turn from good to bad" while in Chinese literature, great sadness is usually followed by small joys, which is the unique feature of reunion. Western tragedies often have extremely tragic endings whereas Chinese classical tragedies often resolute the sufferings in a satisfactory way, and the endings usually provide a sense of hope and comfort, such as redressing a grievance and having it settled in "Snow in Midsummer," being listed as a successful candidate in the "Romance of the Western Chamber," and the meeting on the moon in the "Palace of Eternal Life." Just as Wang Guowei said, "Those who start with sadness end with joy, and those who start with separation end with unio," which explains the pattern of Chinese tragedy. 
The Chinese "happy ending" reflects their aesthetic ideal of "advocating roundness." In the East, the concept of "harmony is beauty" encourages people to purify their emotions whereas the concept of "sorrow at the end" in the West is enough to shock people's soul. The image of Hamlet is unforgettable to readers because he sacrificed himself at last, which reveals the noble tragic implication of human dignity and personality ideal. Therefore, education should not only include elements of happiness but also the realization of the importance of tragedy awareness. Students should be educated to pursue the value and significance of life with struggle and grief, learn to face the tragedy of life, as well as seek the transcendence of life.

\subsubsection{Rationalism}

Rationalism is an important element in western culture. It mainly refers to the ability to start from reality, use rational ability, explore things, and hold on to the scientific aspects.

Many articles about science and technology have been selected to be included in the textbook. These articles are rigorous in logic and precise in language. The inquiry spirit of every scientist to keep improving reflects their love and dedication to truth and science. In contrast to the Chinese' emphasis on "benevolence," Westerners focus on "reason"; they explore the essence of things through logical reasoning, recognize the knowability of the world, and adhere to the pursuit of truth. These reflect the scientific spirit of rationalism. For example, "The Future of the Universe" by Stephen Hawking explores the development of the universe from a scientific perspective, from mature theories to scientific assumptions. On the other hand, "Society as a Creature" is an article on the social nature of organisms. The author has a unique perspective in comparing social organisms with humans and offered unique opinions. Joseph Needham once asked, "Ancient Chinese science and technology had been leading the world, but why did it fall behind the West in modern times?" There are various reasons for this, but the lack of rational scientific spirit must not be neglected.

The development of science drives the development of scientific spirit. On the other hand, scientific spirit also promotes the prosperity of science. Science and technology are the primary productive forces and China has realized the importance of science and technology to the development of a country. In regard to that, China is now vigorously advocating the strategy of rejuvenating the country by science and technology. It is imperative to promote the rejuvenation of the country through science and technology in addition to integrate the cultivation of scientific spirit into Chinese teaching.

\section{Suggestions in the teaching of foreign literature in Chinese high schools}

Although many scholars have realized the importance of learning foreign literature, the argument of "useless foreign literature" and the difficulty in understanding caused by cultural differences are still the biggest obstacles in learning foreign literature.

\subsection{Attaching importance to the interpretation of selected foreign literary works}

Literary works are the bridge of communication among countries, and foreign literary works are windows that reveal their cultures. Therefore, the explanation of foreign literary works should not be neglected, and the educational concept of respecting cultural diversity should be established in teaching activities. In addition, foreign literature reflects different national beliefs and ways of thinking. Hence, it would be beneficial to begin from the subject of national culture to understand and solve problems, rather than restricting to the traditional Chinese thinking. Otherwise, the contents of foreign literary works would be one-sided or even distorted. Therefore, only by changing the teaching concepts and respecting cultural diversity, foreign literary works can be correctly interpreted. 


\subsection{Adopting diversified teaching methods}

In the teaching process of foreign literature, teachers should use flexible and diverse teaching methods. Diversified teaching methods can mobilize students' enthusiasm, and it is also conducive to the modification of the classroom environment. Therefore, based on various texts, teachers and students should form a dialogue while integrating themselves into the texts. This situational teaching can pique students' interest in learning. For example, learning "I Have a Dream," through the understanding of Martin Luther King, teachers can guide students to take up roles to help students better understand the ideal of national freedom and liberation of black leaders.

In addition, teachers can appropriately use transfer and contrast teaching methods during foreign culture teaching. By comparing their similarities and differences, their understanding of works can be promoted. In the teaching of foreign literary works, Chinese and foreign literary works can be compared; similar contents of the Chinese culture can be transferred in the teaching process to break the boundaries between the Chinese and foreign cultures. This would help the students to understand foreign cultures more deeply. For example, in "Credo," it speaks about returning things that have been found. This is exactly the same as the Chinese idiom, "not to the pocket money one has picked up." From this, the values of the East and the West are not that different, and it makes it easier to understand. In "Credo," the author, Fulghum, regards "taking a nap every day" as a life attitude, but in the Chinese national culture, a habit is rarely regarded as a credo or belief; just like three meals a day, which can only be a daily habit to be followed. In the process of comparative teaching, comparing Chinese and foreign cultures is an effective method to help students better understand the works.

\subsection{Expanding students' reading range}

Extracurricular reading can increase students' literary knowledge reserves. Therefore, in learning foreign literature, it is necessary to pay attention to extracurricular reading and expand students' reading range. As guides in students' learning, teachers should not only have excellent professional quality, but also enough knowledge reserve of foreign literature in order to guide students to read foreign literature extensively. Teachers can recommend appropriate foreign literary works to students, communicate and discuss with them, as well as enhance their enthusiasm in learning foreign literature. Only by reading and enriching the knowledge of foreign literary works, students can then have a more scientific understanding of the differences between Chinese and foreign cultures in understanding foreign cultures and improving their humanistic quality while understanding the Chinese traditional culture.

\section{Disclosure statement}

The author declares that there is no conflict of interest.

\section{References}

[1] Ministry of Education of the People's Republic of China, 2012, Chinese Curriculum Standards for Senior High Schools (2017 Edition). Full Time Compulsory Education, Beijing, 3.

[2] Xu X, 2003, Comparison of Chinese and Western Cultures. Peking University Press, Beijing.

[3] Liu H, 2001, Foreign Literature in Middle School Chinese. Journal of Beijing Normal University (Humanities and Social Sciences Edition), (01): 135-41.

[4] Zhang L, 2013, On the Present Situation and Thoughts of Foreign Literature Selection in High School Chinese Textbooks. Educational Theory and Practice, 33(26). 
[5] Chen L, 2019, High School Chinese Textbook: Value Dimension, Content Characteristics and Textbook Use. Basic Education Curriculum, (24): 7-12.

[6] Wang J, 2020, An Analysis of the Teaching of Patriotic Characters in High School Chinese Textbooks. Chinese Journal of Education, (S2): 88-90.

[7] Wang L, Xiao P, 2020, High School Chinese Teaching Strategies Based on Deep Learning. Chinese Construction, (09): 41-5.

[8] Wen R, 2020, "Learning" and "Study" - Discussion on the Writing Intention and Using Suggestion of "Optional Compulsory" in High School Language. Chinese Teaching in Middle School, (08): 4-12.

[9] Bozkus K, 2019, The Attitudes of Teachers Towards Multicultural Education. European Journal of Educational Research, 8(1).

[10] Acar-Ciftci Y, 2019, Multicultural Education and Approaches to Teacher Training. Journal of Education and Leaning, 8(4).

[11] Erüemit AK, 2020, Effects of Different Teaching Approaches on Programming Skills. Education and Information Technologies, 25(2): 1013-37. 